\title{
Field approaches of bacterial biocides and essential oils as integrated control measures against peanut crown rot disease
}

\section{Abdel-Kader MM*, Abdel-Kareem F, El-Mougy NS and El- Gamal NG}

Plant Pathology Dept., National Research Centre, Dokki 12622, Egypt

Abdel-Kader MM*, Abdel-Kareem F, El-Mougy NS, El-Gamal NG 2013 - Field approaches of bacterial biocides and essential oils as integrated control measures against peanut crown rot disease. Plant Pathology \& Quarantine 3(2), 161-170, doi 10.5943/ppq/3/2/5

Lemon grass, thyme and rose essential oils have been found to have inhibitory effects against the mycelial growth of Aspergillus niger under in vitro conditions. Results indicated that all essential oils treatments significantly reduced the linear growth of A. niger. Complete reduction was obtained with thyme and lemongrass at concentration of $0.5 \%$. Moreover, essential oils used to coat seeds and sown in soil drenched with $B$. subtilis resulted in a significant reduction of crown rot incidence of peanut, at both pre- and post-emergence stages under field conditions. Rose, thyme and lemongrass in descending order could reduce the incidence of crown rot at both pre-and postemergence stages at the two successive growing seasons 2011 and 2012. Higher protective effect against crown rot incidence at both pre- and post-emergence growth stages was observed when essential oils integrated with $B$. subtilis as an applied soil treatment than that of individual applied treatment. Also Rhizolex-T as seed treatment could significantly reduce disease incidence over the control treatment. As for the harvested yield, all treatments were significantly higher than that in the control treatment. The treatments of essential oils as seed dressing plus the bio-agent $B$. subtilis showed higher yield production than those treatments using an essential oil or B. subtilis alone. The present results show that application of essential oils in integration with the bio-agent $B$. subtilis may be considered as an applicable, safe and cost-effective method for controlling such soil-borne diseases.

Key words - crown rot - lemongrass oil - Peanut - rose oil - thyme oil - B. subtilis

\section{Article Information}

Received 12 August 2013

Accepted 20 September 2013

Published online 23 October 2013

*Corresponding author: Mokhtar Abdel-Kader - e-mail - mokh_nrc@yahoo.com

\section{Introduction}

Peanut (Arachis hypogaea L.) is attacked by certain soil borne fungi causing root diseases. The main pathogens responsible for crown rot incidence of peanut was reported to be Aspergillus niger (Suzui and Makino,
1980). Crown rot of peanut was found in the sandy and reclaimed soils in Egypt (Nofal et al., 1990; Anonymous, 2010). This disease appears during the growing season at seedling stage of plant growth and many occur earlier at the pre-emergence stage, thus forcing the 
farmer to replant the missed hills or dead plants. Also, it was reported that the fungus Aspergillus niger may cause seed rot and preemergence damping-off of seedlings, the most obvious symptom is the sudden wilting of young plants (Ciegler and Vesonder, 1987; Hawksworth, 1990). The economic importance of Aspergillus crown rot is difficult to assess. Generally scattered plants are affected, although stand losses of 50\% have been reported in isolated fields (Damicone and Melouk, 1990). In Egypt due to the economic importance of peanut, the farmers repeat planting even in the same land, which leads to a high build-up of pathogens, causing serious losses that could reach up to $18 \%$ (Anonymous, 2010). As the management strategy followed by the farmers was considered to be an unwise, intensive use of fungicides, this strategy was not a satisfactory solution for controlling root rot disease.

An investigation of crown rot disease is considered particularly important in light of its wide prevalence in Egypt, particularly in sandy soils. Thus far, due to scientific and practical difficulties, there is no economic way to control root rot disease in many crops. The application of biological controls using antagonistic microorganisms has proved to be successful for controlling various plant diseases in many countries (Sivan and Chet, 1992). Sunick et al. (1997) recorded that Bacillus sp. gave a highly antagonistic effect against some pathogenic fungi including $F$. solani. Moreover, Kim et al., (1997) found that seed treatment with Bacillus spp. actively controlled three fungal root diseases of wheat, and Pseudomonas cepacia or P. fluorescens applied to pea seeds acted as a biological control agent against Pythium damping-off and Aphanomyces root rot and was able to reduce disease incidence (Parke et al. 1991; King and Parke, 1993). In addition, Bacillus cereus has proven to have beneficial effects on crop health including enhancement of soybean yield, suppression of damping-off of tomato (Smith et al., 1999) and alfalfa (Kazmar et al. 2000). Extensive laboratory testing demonstrated a powerful suppression of damping-off of alfalfa by diverse strains of $B$. cereus, which confirmed preliminary testing under field conditions (Handelsman et al., 1990; Kazmar et al., 2000).
On the other hand, there has been a constant search for alternative and efficient compounds for the control of plant pathogens. The aim is a partial or total replacement of antimicrobial chemical fungicides. Essential oils are promising alternative compounds which have an inhibitory activity on the growth of pathogens. It is possible that essential oils could be used in plant disease control as the main or as adjuvant antimicrobial compounds. Recently, there has been considerable demand for the discovery of new natural antimicrobials (Sagdic et al., 2003). Plant products with antimicrobial properties have notably obtained attention as possible applicants in order to prevent bacterial and fungal growth (Lanciotti et al., 2004). Plant products are characterized as having a wide range of volatile compounds. This means that essential oils could be used as alternative anti-bacterial and anti-fungal treatments (Jenny, 2000). It is evident from reviews by Karapinar (1985) and Nanir and Kadu (1987) that some plant extracts and essential oils exhibited antifungal properties. Application of essential oil is a very attractive method for controlling plant diseases. Essential oils and their components are gaining increasing interest because of their relatively safe status, their wide acceptance by consumers, and their exploitation for potential multipurpose functional uses (Ormancey et al., 2001). Recently, interest has been shown in combining microbial biocontrol agents with other chemical components to increase their activity against plant pathogens. Essential oils have been used successfully in combination with a variety of treatments, such as antibacterial agents, mild heat and salt compounds (Karatzas et al., 2000). The increasing interest in pesticide alternatives was due to the toxicity implication of pesticides for humans. Therefore, there will be an increasingly driven demand motivated by different priorities such as health benefits, cost, ecological benefits, ethical issues, food safety and sustainability of supply. Against this background, and the demand for natural products as raw material for new antifungal agents, the objective of the present work was aimed to determine the efficacy of some plant derived essential oils against the growth of peanut crown rot pathogen Aspergillus niger under in vitro conditions. Application of 
Plant Pathology \& Quarantine - Doi 10.5943/ppq/3/2/5

essential oils as seed treatments in combination with the bio-agent Bacillus subtilis as a soil treatment was also evaluated against crown rot incidence of peanut under field conditions.

\section{Materials and Methods}

The present work was developed at the laboratory of Plant Pathology of National Research Centre (NRC), Egypt. The confirmed field experiment was carried out at the Experimental Research Station of National Research Centre at El-Noubareia region, Behera Governorate, Egypt. Tests were performed with the pathogenic fungus Aspergillus niger as well as the antagonistic bacteria Bacillus subtilis which are kept at the culture collection unit of the same laboratory. Pure-grade of the essential oils, i.e. lemongrass (Cymbopogon citrates L.), rose (Rosa centifolia L.) and thyme (Thymus vulgaris L.) were obtained from Cairo Company for oils and aromatic extractions, Cario Industrial Development (CID), Egypt. The essential oils were stored in dark glass bottles.

\section{Laboratory tests:}

Three essential oils (Table 1) at concentrations of $0.25,0.5$ and $1.0 \%$ were evaluated for their inhibitory effect on fungal radial growth, through in vitro tests. Emulsified stocks at high concentrations of tested essential oils were prepared by dissolving in sterilized distilled water. A few drops of the emulsifier Tween 20 (Sigma Co.) were added to the essential oil volumes to obtain an emulsion feature. Different volumes of the essential oil emulsion were added to conical flasks containing $100 \mathrm{ml}$ of sterilized PDA medium before its solidification, to obtain the proposed concentrations. The supplemented media were poured into Petri-dishes $(9 \mathrm{~cm})$ about $20 \mathrm{ml}$ each. The control check treatment was PDA medium which was free of essential oils.

Disks ( $5 \mathrm{~mm}$-diameter) of $A$. niger taken from seven day-old culture were placed on the centre of Petri dishes. All plates were incubated at $25 \pm 2{ }^{\circ} \mathrm{C}$ until the tested fungus reached full growth in the check treatment. Reduction in mycelial growth was calculated as the percentage of fungal growth diameter in the treatment, relative to the growth diameter in the control. Each treatment was represented by 5 plates as replicates. This test repeated three times and the average results were calculated.

\section{Field Experiments:}

The activity of integrated treatment of bio-agent $B$. subtilis and soaked peanut seeds took place with $0.5 \%$ of any of the following essential oils (v:w) lemongrass, rose and thyme against crown rot incidence. Activity of the treatments was evaluated under field conditions. This study was performed in a naturally heavily infested field with peanut crown rot pathogen, at the Experimental Research Station of National Research Centre at El-Noubareia region, Behera Governorate, Egypt during the two successive growing seasons of 2011/2012. A field experiment was established which consisted of $(3.5 \times 6.0 \mathrm{~m})$ plots, composed of 12 rows and a $25 \mathrm{~cm}$ spacing between plants within a row.

The inoculum of bio-agent bacteria $B$. subtilis was grown on Nutrient broth medium and incubated in a rotary shaker at $200 \mathrm{rpm}$ for $24 \mathrm{~h}$ at $28 \pm 1^{\circ} \mathrm{C}$. The bacterial cells were harvested by centrifugation at $6,000 \mathrm{rpm}$ for 10 min, washed twice with $0.05 \mathrm{M}$ phosphate buffer at $\mathrm{pH} 7.0$, and re-suspended in distilled water. The concentration of bacterial cells in the suspensions was adjusted, with the aid of a haemocytometer slide, to $10^{5}-10^{6}$ cells per milliliter. A few drops of the emulsifier Tween 20 (Sigma Co.) were added to the prepared bioagent to obtain a distributed separated spores/cells suspensions. Inoculum of $B$. subtilis inocula as liquid cultures $\left(3 \times 10^{6}\right.$ $\mathrm{cfu} / \mathrm{mL}$ ) was used as soil drench at a ratio of $500 \mathrm{ml} / \mathrm{m}^{2}$ soil. The bacterial inoculum was incorporated into the top $20 \mathrm{~cm}$ of the soil surface at planting row site (Abdel-Kader, 1997).

Peanut seeds (cv. Giza 3) were surface disinfected by immersing in sodium hypochlorite $(2 \%)$ for $2 \mathrm{~min}$, and washed three times with sterilized water, then dried between two sterilized layers of filter paper. The disinfected seeds were coated with a different essential oils tested at the rate of $4 \mathrm{ml} / \mathrm{kg}$ seeds. Seed dressing was carried out by applying the tested essential oil to the gum moistened seeds in polyethylene bags and shaking well to ensure even distribution of the added materials. The treated seeds were then left on a plastic 
tray to air dried. The fungicide Rhizolex-T 50 $\mathrm{WP}$ at the recommended dose $(3 \mathrm{~g} / \mathrm{kg})$ was applied as the seed dressing as stated before. In addition, disinfected, untreated peanut seeds were sown as a comparison treatment.

Three seeds of peanut seeds c.v. Giza 3 per hole were used in all the treatments. Three replicates (plots) per each relevant treatment were used in a completely randomized block design. Plots received the usual agricultural practices, i.e. NPK fertilizer and irrigation etc. Percentage of crown rot incidence at the preand post-emergence of growth stages was investigated and calculated 20 and 90 days after the sowing date. The obtained yield was estimated for each particular treatment as $\mathrm{kg} / \mathrm{plot}$ at the end of experiment. Recorded data as the obtained results of the two growing seasons were calculated as the average percentages of pre-, and post-emergence crown rot incidence as well as the produced yield.

The average percentage of peanut crown rot incidence was recorded until 90 days of sown. Determination of yield per $\mathrm{m}^{2}$ was also calculated.

\section{Statistical analysis:}

All in vitro and in vivo experiments were set up in a completely randomized design. One way analysis of variance (ANOVA) was used to analyze the obtained results concerning the following: 1. Differences between the tested essential oil inhibitor effect and linear growth of pathogenic fungi in vitro, 2 . Differences between integrated treatments of seed dressing with essential oils and bio-agent against crown rot pathogens, under field conditions. General Linear Model option of the Analysis System SAS (SAS, 1996) was used to perform the analysis of variance. Duncan's Multiple Range Test at $p<0.05$ level was used for means separation (Winer, 1971).

\section{Results and Discussion}

\section{Laboratory tests:}

The essential oils evaluated in this work have a great variety of phytochemicals (Table 1) that could be considered as responsible for a larger or smaller antifungal activity.

Those phytochemicals are as follows: 1 . citrol or citral in lemongrass essential oil; 2 . citronellol, geraniol, nerol, stearoptene, $\alpha$ pinene, $\beta$-pinene, $\alpha$-terpinene, limonene, camphene, $\beta$-caryophyllene, citronellyl acetate, eugenol in rose essential oil; 3. Thymol, carvacrol, geraniol, thymol methyl ether, $\alpha$ pinene in thyme essential oil; ( $C$.f. herb information: www.holisticonline.com/HerbalMed/_Herbs/h280.htm ).

Table 1 Botanical plant classification and main active principles of their essential oil*

\begin{tabular}{|c|c|c|c|}
\hline $\begin{array}{l}\text { Common } \\
\text { name }\end{array}$ & $\begin{array}{l}\text { Scientific } \\
\text { name }\end{array}$ & Family & $\begin{array}{c}\text { Major } \\
\text { active component }\end{array}$ \\
\hline Lemongrass & $\begin{array}{l}\text { Cymbopogon } \\
\text { citrates } \mathrm{L} .\end{array}$ & Poaceae & citrol or citral \\
\hline Rose & $\begin{array}{c}\text { Rosa } \\
\text { centifolia } \mathrm{L} .\end{array}$ & Rosaceae & $\begin{array}{l}\text { citronellol, geraniol, nerol, stearoptene, } \\
\alpha \text {-pinene, } \\
\beta \text {-pinene, } \\
\alpha \text {-terpinene, limonene, camphene, } \\
\beta \text {-caryophyllene, citronellyl acetate, eugenol. }\end{array}$ \\
\hline Thyme & $\begin{array}{l}\text { Thymus vulgari } \\
\text { L. }\end{array}$ & Lamiaceae & $\begin{array}{l}\text { thymol, carvacrol, geraniol, thymol methyl ether, } \\
\alpha \text {-pinene }\end{array}$ \\
\hline
\end{tabular}

*According to Joy et al. (2001)

The inhibitory effect of lemongrass, rose and thyme essential oils against the my- celia growth of plant pathogenic fungus $A$. niger presented in Table (2). 
Table 2 Inhibitory effect of different essential oils on Aspergillus niger in vitro

\begin{tabular}{|c|c|c|c|}
\hline \multirow[b]{2}{*}{ Essential oil } & \multirow[b]{2}{*}{$\begin{array}{c}\text { Concen. } \\
\%\end{array}$} & \multicolumn{2}{|c|}{ Aspergillums niger } \\
\hline & & $\begin{array}{c}\text { Linear growth } \\
(\mathbf{m m})\end{array}$ & $\begin{array}{c}\text { Growth reduction } \\
\% \\
\end{array}$ \\
\hline \multirow{3}{*}{ Lemongrass } & 0.25 & $31.0 \mathrm{c}$ & 65.6 \\
\hline & 0.50 & $0.0 \mathrm{~d}$ & 100.0 \\
\hline & 1.0 & $0.0 \mathrm{~d}$ & 100.0 \\
\hline \multirow{3}{*}{ Rose } & 0.25 & $62.0 \mathrm{~b}$ & 31.1 \\
\hline & 0.50 & $30.0 \mathrm{c}$ & 66.7 \\
\hline & 1.0 & $28.0 \mathrm{c}$ & 68.9 \\
\hline \multirow{3}{*}{ Thyme } & 0.25 & $35.0 \mathrm{c}$ & 61.1 \\
\hline & 0.50 & $0.0 \mathrm{~d}$ & 100.0 \\
\hline & 1.0 & $0.0 \mathrm{~d}$ & 100.0 \\
\hline Control & 0.0 & $90.0 \mathrm{a}$ & -- \\
\hline
\end{tabular}

Figures with the same letter are not significantly different $(\mathrm{p}<0.05)$

Fungal mycelia growth decreased significantly as the concentrations of essential oils were increased, to reach the fungal growth's minimum at the highest concentration used. Complete inhibition in fungal growth was observed with $0.5 \%$ of lemongrass and thyme essential oils. Mycelial growth of A. niger showed more tolerance to rose essential oil that its growth reduced by $68.9 \%$ at the highest concentration used as $1.0 \%$. Similar results were also reported concerning the efficacy of essential oils as antifungal inhibitors. Akgul and Kivanc (1988) studied antifungal activity of selected Turkish spices (black cumin, coriander, cumin, dill, laurel, oregano, parsley, spearmint, white mustard) on some food-borne fungi. They found that ground $(1.0,1.5,2.0 \%$ w/v) plus essential oil $(0.05 \%, 0.025 \%)$ showed an inhibitory effect on Aspergillus flavus, A. niger, Geotricum candidum, Mucor spp. and Penicillium roqueforti. Also, El-Mougy et al., (2007) reported that $4 \%$ of the tested essential oils geranium, rose, lemon and mint have an inhibitory effect against the mycelial growth of $R$. solani and $F$. oxysporum $\mathrm{f}$. sp. phaseoli under in vitro, causing complete inhibition in fungal growth. Furthermore, ElToony et al. (2003) studied the biochemical reaction of onion, garlic, eucalyptus, caraway, fennel, black cumin, mustard, carnation, neemix and trilogy essential oils against mycelial growth of $R$. solani and Pythium debaryanum in vitro. They found that complete inhibition of both fungi was obtained by only carnation oil at $4 \%$, however considerable inhibition (more than 90\%) was obtained with neemix and trilogy oils.

\section{Field experiments:}

The efficacy of essential oils as seed coating sown together with the bio-agent $B$. subtilis as soil drench against the incidence of crown rot diseases of peanut was evaluated under field conditions. Data in Table (3) and Fig. (1) clearly demonstrate that all treatments significantly reduced disease incidence compared with the control. Rose, thyme and lemongrass in descending order could reduce the incidence of crown rot at both pre-and postemergence stages by $(25.7,33.2$ - 32.4, $32.0 \%)$; $(48.5,56.6-54.0,54.0 \%)$ and (58.5, $58.4-56.7,60.0 \%)$ at the two successive growing seasons 2011 and 2012, respectively, compared to $(80.0,75.4-75.6,81.6 \%)$ in case of the fungicide Rhizolex-T (Table, 4). Higher protective effect against crown rot incidence at both pre- and post-emergence growth stages was observed when essential oils integrated with B. subtilis as an applied soil treatment. A similar trend was observed regarding the applied treatments. Treatment of lemongrass plus $B$. subtilis had the greatest effect on disease incidence whereas reduction in crown rot was recorded at the two successive growing seasons 2011 and 2012 as 78.5, 73.5\% and $75.6,82.0 \%$ at pre- and post-emergence stages, respectively. Similarly, treatment of thyme plus B. subtilis reduced disease incidence by 76.0 , $77.3 \%$ and $74.3,79.6 \%$ in respective order at pre- and post-emergence stages for 2011 and 2012 growing seasons (Table, 4). A high significant effect was observed when using the Rhizolex-T as seed treatment which reduced disease incidence by 80.0, $75.4-75.6,81.6 \%$, also Rhizolex-T treatment could significantly 
Table 3 Incidence of peanut crown rot caused by $A$. niger in response to seed dressings with essential oils and soil drench with $B$. subtilis under field conditions

\begin{tabular}{|c|c|c|c|c|}
\hline \multirow{3}{*}{ Treatment } & \multicolumn{4}{|c|}{ Crown rot incidence $(\%)$} \\
\hline & \multicolumn{2}{|c|}{ Growing season, 2011} & \multicolumn{2}{|c|}{ Growing season, 2012} \\
\hline & $\begin{array}{l}\text { Pre- } \\
\text { emergence }\end{array}$ & $\begin{array}{r}\text { Post- } \\
\text { emergence }\end{array}$ & $\begin{array}{c}\text { Pre- } \\
\text { emergence }\end{array}$ & $\begin{array}{l}\text { Post- } \\
\text { emergence }\end{array}$ \\
\hline Lemongrass & $14.5 \mathrm{c}$ & $22.0 \mathrm{c}$ & $16.0 \mathrm{c}$ & $20.0 \mathrm{c}$ \\
\hline Rose & $26.0 \mathrm{~b}$ & $35.4 \mathrm{~b}$ & $25.0 \mathrm{~b}$ & $34.0 \mathrm{~b}$ \\
\hline Thyme & $18.0 \mathrm{c}$ & $23.0 \mathrm{c}$ & $17.0 \mathrm{c}$ & $23.0 \mathrm{c}$ \\
\hline B. subtilis & $17.0 \mathrm{c}$ & $21.0 \mathrm{c}$ & $14.0 \mathrm{c}$ & $22.0 \mathrm{c}$ \\
\hline $\begin{array}{l}\text { B. subtilis }+ \\
\text { Lemongrass }\end{array}$ & $7.5 \mathrm{~d}$ & $14.0 \mathrm{~d}$ & $9.0 \mathrm{~d}$ & $9.0 \mathrm{~d}$ \\
\hline $\begin{array}{l}\text { B. subtilis + } \\
\text { Rose }\end{array}$ & $16.0 \mathrm{c}$ & $23.2 \mathrm{c}$ & $14.0 \mathrm{c}$ & $18.0 \mathrm{c}$ \\
\hline $\begin{array}{l}\text { B. subtilis + } \\
\text { Thyme }\end{array}$ & $8.4 \mathrm{~d}$ & $12.0 \mathrm{~d}$ & $9.5 \mathrm{~d}$ & $10.2 \mathrm{~d}$ \\
\hline Rhizolex-T 50\% & $7.0 \mathrm{~d}$ & $13.0 \mathrm{~d}$ & $9.0 \mathrm{~d}$ & $9.2 \mathrm{~d}$ \\
\hline Control & $35.0 \mathrm{a}$ & $53.0 \mathrm{a}$ & $37.0 \mathrm{a}$ & $50.0 \mathrm{a}$ \\
\hline
\end{tabular}

Figures with the same letter are not significantly different $(\mathrm{p}<0.05)$

reduce disease incidence over the control treatment (Table, 4).

As for the harvested yield, all treatments were significantly higher than that in the control treatment. The treatments of essential oils as seed dressing plus the bioagent $B$. subtilis showed higher yield production than those treatments using an essential oil or B. subtilis alone. Data in Table (5) showed high effective treatments of essential oils plus $B$. subtilis which helped increase peanut yield whereas thyme recorded an increase of 52.6, 67.4\%; followed by lemongrass $52.6,69.8 \%$ and $36.8,44.2 \%$ at the two successive growing seasons 2011 and 2012, respectively. Seeds coated with essential oils only, caused a yield increase estimated between $13.2-39.5 \%$ and $11.5-44.1 \%$ at the two successive growing seasons 2011 and 2012 , in respective order. High increase in peanut yield (47.4 and $62.8 \%$ ) was observed with seed coated with the fungicide Rhizolex-T over the check control treatment.

Table 4 Reduction in peanut crown rot incidence caused by A. niger in response to seed dressings with essential oils and soil drench with $B$. subtilis under field conditions

\begin{tabular}{|c|c|c|c|c|}
\hline \multirow{3}{*}{ Treatment } & \multicolumn{4}{|c|}{ Crown rot reduction (\%) } \\
\hline & \multicolumn{2}{|c|}{ Growing season, 2011} & \multicolumn{2}{|c|}{ Growing season, 2012} \\
\hline & $\begin{array}{c}\text { Pre- } \\
\text { emergence }\end{array}$ & $\begin{array}{c}\text { Post- } \\
\text { emergence }\end{array}$ & $\begin{array}{r}\text { Pre- } \\
\text { emergence }\end{array}$ & $\begin{array}{l}\text { Post- } \\
\text { emergence }\end{array}$ \\
\hline Lemongrass & 58.5 & 58.4 & 56.7 & 60.0 \\
\hline Rose & 25.7 & 33.2 & 32.4 & 32.0 \\
\hline Thyme & 48.5 & 56.6 & 54.0 & 54.0 \\
\hline B. subtilis & 51.4 & 60.3 & 62.1 & 56.0 \\
\hline $\begin{array}{l}\text { B. subtilis + } \\
\text { Lemongrass }\end{array}$ & 78.5 & 73.5 & 75.6 & 82.0 \\
\hline $\begin{array}{l}\text { B. subtilis + } \\
\text { Rose }\end{array}$ & 54.2 & 56.2 & 62.1 & 64.0 \\
\hline $\begin{array}{l}\text { B. subtilis }+ \\
\text { Thyme }\end{array}$ & 76 & 77.3 & 74.3 & 79.6 \\
\hline Rhizolex-T $50 \%$ & 80 & 75.4 & 75.6 & 81.6 \\
\hline
\end{tabular}




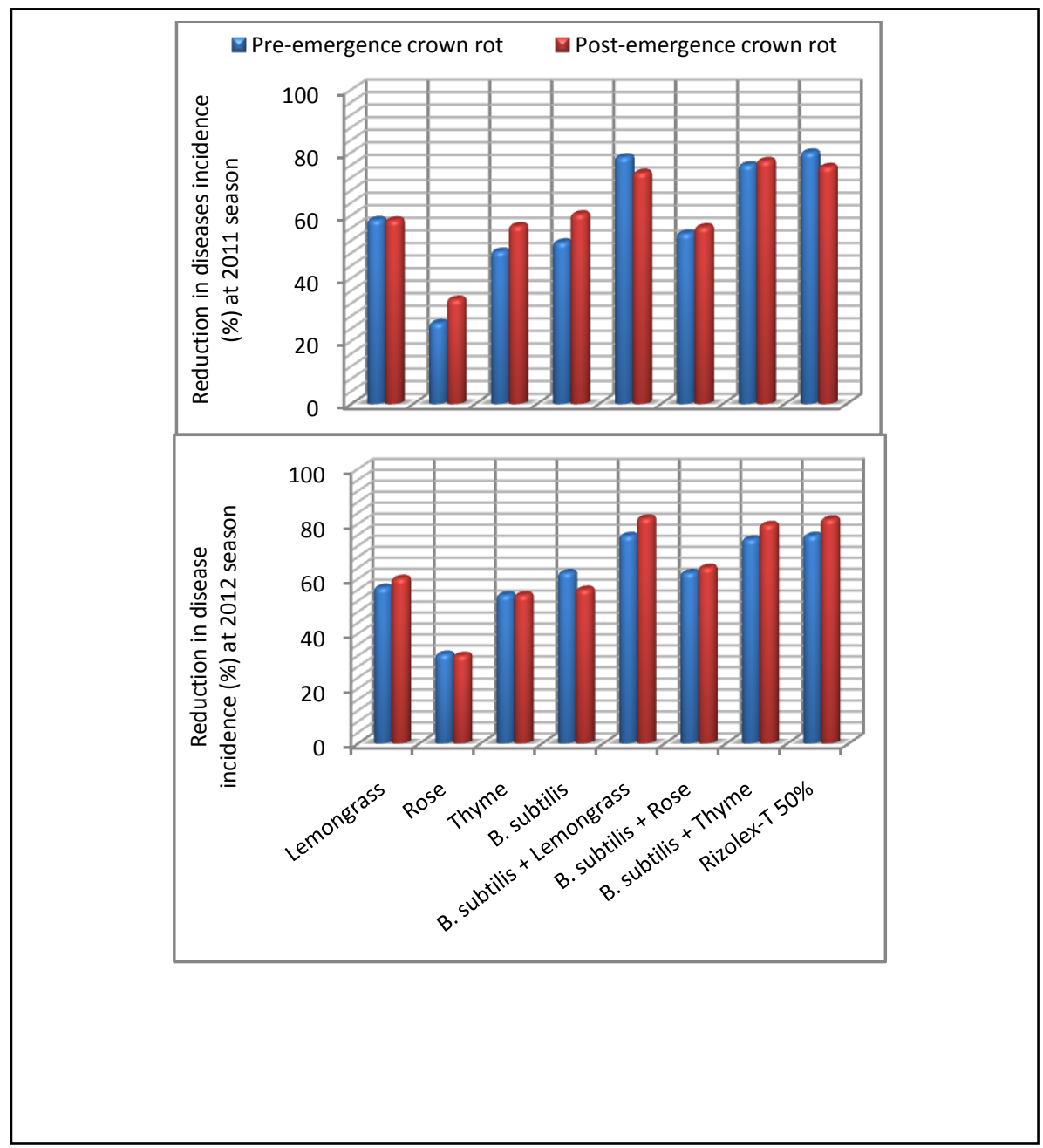

Fig. 1 Reduction in peanut crown rot incidence caused by A. niger in response to seed dressings with essential oils and soil drench with $B$. subtilis under field conditions.

Table 5 Peanut yield in response to seed dressings with essential oils and soil drench with $B$. subtilis under field conditions

\begin{tabular}{|c|c|c|c|c|}
\hline \multirow[b]{2}{*}{ Treatment } & \multicolumn{2}{|c|}{ Growing season, 2011} & \multicolumn{2}{|c|}{ Growing season, 2012} \\
\hline & Yield $\mathrm{Kg} / \mathrm{m}^{2}$ & Increase \% & Yield $\mathrm{Kg} / \mathrm{m}^{2}$ & Increase \% \\
\hline Lemongrass & $5.3 \mathrm{~b}$ & 39.5 & $6.0 \mathrm{~b}$ & 39.5 \\
\hline Rose & $4.3 \mathrm{~d}$ & 13.2 & $4.8 \mathrm{c}$ & 11.5 \\
\hline Thyme & $5.0 \mathrm{~b}$ & 31.6 & $6.2 \mathrm{~b}$ & 44.1 \\
\hline B. subtilis & $5.2 \mathrm{~b}$ & 36.8 & $6.0 \mathrm{~b}$ & 39.5 \\
\hline $\begin{array}{l}\text { B. subtilis }+ \\
\text { Lemongrass }\end{array}$ & $5.8 \mathrm{a}$ & 52.6 & $7.2 \mathrm{a}$ & 67.4 \\
\hline $\begin{array}{l}\text { B. subtilis }+ \\
\text { Rose }\end{array}$ & $5.2 \mathrm{~b}$ & 36.8 & $6.2 \mathrm{~b}$ & 44.2 \\
\hline $\begin{array}{l}\text { B. subtilis + } \\
\text { Thyme }\end{array}$ & $5.8 \mathrm{a}$ & 52.6 & $7.3 \mathrm{a}$ & 69.8 \\
\hline Rhizolex-T 50\% & $5.6 \mathrm{a}$ & 47.4 & $7.0 \mathrm{a}$ & 62.8 \\
\hline Control & $3.8 \mathrm{c}$ & -- & $4.3 \mathrm{~d}$ & -- \\
\hline
\end{tabular}

Figures with the same letter are not significantly different $(\mathrm{p}<0.05)$ 
The present investigation has demonstrated the antifungal activity of all treatments tested. This work proves that some essential oils have potential and could be useful when integrated with bio-agents against peanut fungal pathogen. From the earlier reports (Dabur et al., 2007; Bindu and Kumar, 2009) it is evident that some of the plant products have antifungal compounds which do have the capacity to inhibit the fungal pathogens. Therefore, there is increasing interest in obtaining alternative antimicrobial agents for use in plant disease control systems. One of the main procedures used in the research of biologically active substances is a systematic screening for the interaction between microorganisms and plant products. This procedure has been a source of useful agents to control the microbial survival (Salvat et al., 2001).

Plant products of a recognized antimicrobial spectrum could appear in food conservation systems as main antimicrobial compounds or as adjuvant to improve the action of other antimicrobial compounds (Kaur and Arora, 1999). Among other chemical products, aromatic plants possess essential oils resulting from secondary metabolism. These substances have a great economic potential, especially in the food, pharmaceutical and perfumery sectors. Thus, the number of studies on the chemical composition and biological properties of these oils, as well as the taxonomic, environmental and cultivation factors that lead to variation in their quantity and quality, has been increasing (Simões et al., 2003). On the other hand, Nirmala et al. (1988) showed that essential oil of Juniperus communis may be applicable against a range of damping-off diseases. Kumar and Tripathi (1991) mentioned that extracts of Eupartrium cannabinum completely inhibited the mycelia growth of Pythium de-baryanum, $R$. solani and $S$. rolfsii. Furthermore, Juglal et al. (2002) studied the effectiveness of nine essential oils to control the growth of mycotoxins producing moulds and noted that, clove, cinnamon and oregano were able to prevent the growth of Aspergillus parasiticus and Fusarium moniliforme. Benkeblia (2004) observed the inhibitory effect of onion essential oil at different concentrations, on the growth of $F$. oxysporum, Aspergillus niger and Penicillium cyclopinum. Furthermore, El-Mougy et al.
(2007) reported that geranium, rose, lemon and mint essential oils were tested as seed coating and/ or foliar spray. They added that a significant reduction in root rot and wilt incidence of bean at both pre- and postemergence stages were recorded under greenhouse conditions.

In the present study the introduction of the bio-agent $B$. subtilis to the soil increased the efficacy of essential oils against crown rot incidence under field conditions. Similar results were reported by Abdel- Kader (1997). He stated that $T$. harzianum introduced to the soil was able to reduce root rot incidence of faba bean plants significantly more than the fungicide Rhizolex-T. Moreover, the application of biological controls using antagonistic microorganisms has proved to be successful for controlling various plant diseases in many countries (Chao et al., 1986; Sivan, 1987; El-Mougy, 2001; Wright et al., 2003; El-Mougy and Abdel-Kader, 2008).

\section{Conclusion}

The present study demonstrated that lemongrass, rose and thyme essential oils were found to have an inhibitory effect against the mycelial growth of $A$. niger under in vitro conditions. Moreover, application of an essential oil as a seed coating sown in treated soil with the bio-agent $B$. subtilis as integrated treatment under field trails, resulted in a significant reduction in crown rot incidence of peanut. It may be concluded that application of essential oils combined with bio-agent $B$. subtilis is considered an applicable, safe and cost-effective method for controlling such soilborne diseases.

\section{Acknowledgement}

This work was supported financially by the National Research Centre Fund (NRC), Egypt, Grant No. 9050204.

\section{References}

Abdel-Kader MM. 1997 - Field application of Trichoderma harzianum as biocide for control of bean root rot disease. Egypt. J. Phytopathol. 25, 19-25.

Akgul A, Kivanç M 1988 - Inhibitory effect of selected Turkish spices and oregano components on some foodborne fungi. 
Int. J. Food Microbiol. 6, 263-268.

Anonymous 2010 - 'Yearbook of statistics of Ministry of Agriculture'. (Agricultural Economical and Statistical Department, Arab Republic of Egypt: Cairo) [In Arabic].

Benkeblia N 2004 - Antimicrobial activity of essential oils extracts of various onions (Allium cepa) and garlic (Allium sativum). Lebensm. Wiss. U. Technol. 37, 263-268.

Bindu S, Kumar P 2009 - In vitro antifungal potency of some plant extracts against Fusarium oxysporum. Int. J. Green Pharmacy 3, 63-65.

Chao WL, Nelson EB, Harman GE, Hoch HC 1986 - Colonization of the rhizosphere by biological control agents applied to seeds. Phytopathology 76, 60-65.

Ciegler A, Vesonder RF 1987 - Microbial food and feed toxicants: fungal toxins, pp. 19126. In The CRC handbook of microbiology, Volume VIII. CRC Press, Boca Raton, FL.

Dabur R, Gupta A, Mandal TK, Singh DD, Bajpai V, Gurav AM, Lavekar GS 2007 - Antimicrobial activity of some Indian medicinal plants. Afr. J. Tradition, CAM 4 (3), 313-318.

Damicone H, Melouk H 1990 - Soilborne Diseases of Peanut. Oklahoma Cooperative Extension Service. EPP7664:

$1-7$. http://pods.dasnr.okstate.edu/docushare/d sweb/Get/Document-2617/EPP-

7664web.pdf

El-Mougy NS 2001 - Field application of certain biological and chemical approaches on controlling Bean wilt disease. Egypt. J. Phytopathol. 29, 6978.

El-Mougy NS, Abdel-Kader MM 2008 - Long term activity of bio-priming seed treatment for biological control of faba bean root rot pathogens. Australian Plant Pathol. 37 (5), 464-471.

El-Mougy NS, El-Gamal NG, Abdel-Kader MM 2007 - Control of wilt and root rot incidence in Phaseolus vulgaris L. by some volatile compounds. J. Plant Protection Res. 47 (3), 255-265.
El-Toony AME, Awad NGH, Tadrous MFI 2003 - Chemical and biochemical control of tomato damping-off disease under nursery conditions with special reference to the antagonism between the causal pathogens. Egypt. J. Appl. Sci. 18, 47-68.

Handelsman J, Raffel S, Mester EM, Wunderlich L, Grau CR 1990 Biological control of damping-off of alfalfa seedlings with Bacillus cereus UW85. Appl. Environ. Microbiol. 56, 713-718.

Hawksworth DL 1990 - Problems and prospects for improving the stability of names in Aspergillus and Penicillium. In R.A. Samson and J.I. Pitt, (eds.), Modern concepts in Penicillium and Aspergillus classification. NATO Advanced Science Institute Series, Series A: Life Sciences, Volume 185. Plenum Press, NY (1).

Jenny J 2000 - Essential oils: A new idea for postharvest disease control. Good Fruit and Vegetables magazine 11 (3), pp. 50 .

http://postharvest.com.au/GFV_oils.PD $\mathrm{F}$

Joy PP, Thomas J, Mathew S, Skaria BP 2001 -Medicinal Plants. Tropical Horticulture Vol. 2 (eds. Bose TK, Kabir J, Das P, Joy PP). Naya Prokash, Calcutta, pp. 449-632

Juglal S, Govinden R, Odhav B 2002 - Spices oils for the control of co-occurring mycotoxin-producing fungi. J. Food Protect. 65, 638-687.

Karapinar M 1985 - The effects of citrus oil and some Turkish spices on growth and aflatoxin production by Aspergillus parasiticus NRRL 2999. Int. J. Food Microbiol. 12, 239-245.

Karatzas AK, Bennik MH, Smid EJ, Kets EP 2000 - Combined action of S-carvone and mild heat treatment on Listeria monocytogenes Scott A. J. Appl. Microbiol. 89, 296-301.

Kaur J, Arora D 1999 - Antimicrobial activities of species. Int. J. Antimicrob. Agents 12, 257-262.

Kazmar ER, Goodman RM, Grau CR, Johnson DW, Nordheim EV, Undersander DJ, 
Handelsman JO 2000 - Regression analyses for evaluating the influence of Bacillus cereus on alfalfa yield under variable disease intensity. Phytopathology 90, 657-665.

Kim DS, Cook RJ, Weller DM 1997 - Bacillus sp. L324--92 for biological control of three root diseases of wheat grown with reduced tillage. Phytopathology 87, 551-558.

King EB, Parke JL 1993 - Biocontrol of Aphanomyces root rot and Pythium damping-off by Pseudomonas cepacia AMMD on four pea cultivars. Pl. Dis. 77, 1185-1188.

Kumar A, Tripathi SC 1991 - Evaluation of the leaf juice of some higher plants for their toxicity against soilborne pathogens. Pl. Soil 132, 297-301.

Lanciotti R, Gianotti A, Patrignani N, Belleti N, Guerzoni ME, Gardini F 2004 - Use of natural aroma compounds to improve shelf-life of minimally processed fruits. Trends Food Sci. Technol. 15, 201208.

Nanir SP, Kadu BB 1987 - Effect of some medicinal plants extract on some fungi. Acta Botanica India 15, 170-175.

Nirmala KS, Dubey NK 1988 - Fungitoxic activity of essential oil of Juniperus communis. Indian Perfunm. 33, 25-29.

Nofal MA, Seif-El-Nasr HI, Diab MM, ElNagar MAA, El-Said SIA 1990 - Effect of the systemic fungicides benlate and vitavax-captan on Aspergillus crown rot incidence of peanut plants. Annals of Agricultural Science, Ain-Shams Univ., Cairo., 35, 407-415.

Ormancey X, Sisalli S, Coutiere P 2001 Formulation of essential oils in functional perfumery. Parfums, Cosmetiques, Actualites 157, 30-40.

Parke JL, Rand RE, Joy AE, King EB 1991 Biological control of Pythium dampingoff and Aphanomyces root rot of peas by application of Pseudomonas cepacia or P. fluorescens to seed. Pl. Dis. 75, 987-992.
Sagdiç O, Karahan AG, Ozcan M, Ozcan G 2003 - Effect of some spices extracts on bacterial inhibition. Int. Food Sci. Technol, 9, 353-359.

Salvat A, Antonnacci L, Fortunato RH, Suarez EY, Godoy HM 2001 - Screening of some plants from Northern Argentine for their antimicrobial activity. Lett. Appl. Microbiol. 33, 93-297.

SAS Institute Inc. 1996 - SAS/STAT User's Guide. Version 6, 12th ed. Vol. 2, SAS Institute, Inc. Cary, North Carolina, USA, 846 pp.

Simoes CMO, Schenkel EP, Gosmann G, Mello JCP, Mentz LA, Petrovick PR 2003 - Pharmacognosy of the Plant Medicine. $5^{\text {th }}$ ed., UFRGS / UFSC: Porto Alegre / Flori -Anopolis, 214 pp.

Sivan A 1987 - Biological control of Fusarium crown rot of tomato by Trichoderma harzianum under field conditions. Pl. Dis. 71, 587-592.

Sivan A, Chet I 1992 - Microbial control of plant disease. In: Mitchell $\mathrm{R}$ (ed) Environmental microbiology. Wiley, New York, pp 335-354.

Smith KP, Handelsman J, Goodman RM 1999 - Genetic basis in plants for interactions with disease-suppressive bacteria. Proceedings of the National Academy of Sciences of the United States of America 96, 4786-4790.

Sunick K, Sungjoon Y, Honggi K 1997 Selection of antagonistic bacteria for biological control of ginseng diseases. Korean J. Pl. Pathol. 13, 342-348.

Suzui T, Makino T 1980 - Occurrence of Aspergillus crown rot of peanut caused by Aspergillus niger van Tieghem. Annals of the Phytopathological Society of Japan. 46, 46-48.

Winer BJ 1971 - Statistical Principles in Experimental Design. 2nd ed. MiGrawHil Kogakusha, LTD, 596 pp.

Wright B, Rowse HR, Whipps JM 2003 Application of beneficial microorganisms to seeds during drum priming. Biocontrol Sci. Technol. 13, 599-614. 